\title{
AUTOMATED PROCESSING OF SUBCONTRACTOR WORK PERFORMANCE DATA TO IMPROVE THE QUALITY CONTROL AND SUPPORT THE SUBCONTRACTOR SELECTION PROCESS
}

\author{
Tatjana Vilutienė \\ Dept of Construction Technology and Management \\ Vilnius Gediminas Technical University, Saulètekio al. 11, 10223 Vilnius, Lithuania \\ Tatjana.Vilutiene@st.vgtu.lt
}

\begin{abstract}
The paper presents the research aimed to find the way for efficient monitoring and control of subcontractor performance in large construction projects. As a result the procedure for recording and processing the nonconformities is proposed. Procedure consists of the following stages: the identification of nonconformity (defect, work performed is at variance with project, the requirements of work or environment safety are violated, etc.); construction manager or engineer fills the nonconformity report for subcontractor; engineer puts the information about the nonconformity in the register were it is automatically processing and visualizing in form of tables and diagrams. For processing the data the classifier of nonconformities for register was proposed. According to classifier the nonconformities are sorting by the following attributes: 1) nonconformity to quality requirements; 2) nonconformity to requirements of work safety; 3) nonconformity to requirements of environment safety. Each of these groups has the subgroups for classifying, which let to gain the more precise information about the nature of nonconformity. Information of register is regular, up to date and useful for different company activities involved in construction process. For example, procurement department could use this information in subcontractor prequalification and selection process for further construction projects, construction managers could organize the monitoring of subcontractors works more effectively, for the information in register gives the awareness of how frequently and what kind of nonconformities are usually done by subcontractors.
\end{abstract}

\section{KEYWORDS}

Sub-contractor; Performance evaluation; Monitoring; Quality control; Data collection; Nonconformity

\section{INTRUDUCTION}

The large construction projects are implementing as a rule with participating of many subcontractors. Monitoring and control of subcontractors' works becomes difficult task when in construction process participate a great number of subcontractors. In coordinating many participants of construction process the risk of unnoticed defects and additional costs is inevitably arises. In spite of this fact project team have to apply the means which let more effectively 
monitor the processes on construction site, process the data of work flow, transfer the information to the related personnel. The means for monitoring and control have to be easily applicable, understandable for construction site personnel. The purpose of the research is to find the way for efficient monitoring and control of subcontractor performance in large construction projects.

Quality control is one of the major concerns for the practitioners of the construction industry, in addition to time and cost. The aim of all control procedures is to provide a quality product that is satisfactory to the stakeholders of different parties, compliant with the statutory and industry standards, completion on schedule, within budget and so on. Obviously, the quicker and more information of site activities and worker behaviors the project stakeholders know, the higher the possibility to avoid undesirable outcomes [1]. Therefore, site monitoring plays a critical role nowadays in such a way that it provides information for the project manager to develop contingency plans to preventing structural disaster. For instance, the rate of defects in construction projects could be minimized if the construction processes are closely monitored and examined throughout the construction process. Research reports show that significant part of construction cost is wasted due to rework of defective components detected late in the construction phase [2]. Indeed, most construction defects and accidents are related to human factors such as unskilled workers or insufficient supervision in construction projects $[1,3]$. The accident situation in the construction industry determined mostly by the specifics of the construction activities, which have many features conducive to accidents such as: work on different construction sites, work conditions differing between sites, subcontracting, a wide range of construction processes, a large number of machines and devices posing different hazards, the seasonal character of construction work and the effect of atmospheric conditions on the work environment [4-6].

If project team members could obtain the site information timely, it is believed that some human errors could be eliminated.

Site monitoring in construction quality control does not only minimize construction defects and human errors but also supports project team members making strategic decisions at critical points throughout the construction stages [1]. For example, up to date information could be used in subcontractors selection process and ensure the impartial selection of subcontractor.

Existing methods for tracking and managing the inspection in construction utilize manual recording by paper-based documents. However, information collected using such labor-intensive methods is unreliable and ineffective; inputting, retrieving, analyzing and disseminating the result data require a significant amount of time and effort [7].

Recently in construction industry for large-scale projects that involve many organizations different web-based monitoring systems that integrates wireless technologies, network cameras and a web platform are proposed. For instance, for quality control S. Leung et al (2008) [1] presents a cost-effective construction site monitoring system integrating a long-range wireless network, network cameras, and a web-based collaborative platform.

During the bidding process, selecting the most appropriate sub-contractors for the relevant sub-works is highly critical for the overall project performance. In order to select the most appropriate subcontractors for the project, general contractors have to know general information about these subcontractors. Arslan e al. (2008) [8] proposes a webbased sub-contractor evaluation system called WEBSES by which the sub-contractors can be evaluated based on a combined criterion.

Ng and Li (2006) [9] propose the automated negotiation using the Multi-Agent System (MAS) concept which can reduce the response time and maximize the expected profit should a suitable negotiation protocol be devised. Yang et al. (2007) [10] analyze the problem of selection the Enterprise Resource Planning (ERP) system for construction company. The primary functions of ERP are to integrate the inter-departmental operation procedures and Management Information System (MIS) modules, and to reallocate the resources of a company. The main difficulties for general contractors in applying ERP are the complexities of their working processes and habits. Another problem is the performance level of 
the subcontractors should be included in ERP implementation to maximize the associated benefits. Achieving this is difficult in the construction industry because the general level of computerization is low compared to other industries [10]. Implementation of new technologies should consider all participants in the construction process.

Construction projects involve a high degree of complex procurement processes. Kadefors et al. (2007) [11] show how procurement practice is influenced by goals of innovation and collaboration, and discuss implications for the spreading of new practice in this area.

Jang and Skibniewski (2008) [12] present a new prototype framework of automated tracking and monitoring system that will address the needed shift from the time-and-labour-intensive legacy systems into sensor-and-network-based tracking and monitoring systems for construction materials.

Arslan et al. (2006) [13] propose the e-technology can reduce these demands by improving the efficiency, speed and accuracy of the bidding process.

Researches on selection theory and practice often aim at developing methods and tools [14-19]; more often there is emphasis on determining the criteria used in contractor prequalification and selection [20-25]. Ling (2004) [26] study identifies 60 factors that may affect the design-build project performance and finds that contractor characteristics are the key determinants that affect the most number of performance metrics.

In spite of these facts, it obviously, that quality inspection and monitoring of work performance on construction site plays an essential role in the construction industry: it should be an integral part of daily work on construction site, so that the processes are maintained daily, and the execution of tasks is documented. Various staff and engineers on construction site need to monitor and assess the quality of work performed. A simple to use system for managing and inspecting quality data for projects should be useful also for main office staff performing support functions for project. For example, procurement department could use this information in subcontractor prequalification and selection process for further construction projects, construction managers could organize the monitoring of subcontractors works more effectively, through the awareness of how frequently and what kind of nonconformities are usually done by subcontractors.

\section{DESCRIPTION OF PROCEDURE}

Procedure consists of the following stages: inspection on site; the identification of nonconformity (defect, work performed is at variance with project, the requirements of work or environment safety are violated, etc.); construction manager or engineer fills the nonconformity report for subcontractor; engineer puts the information about the nonconformity in the register were it is automatically processing and visualizing in form of tables and diagrams; processed data transferring to procurement manager; later stored data could be used in prequalification procedure. The actions need to perform are graphically presented in figure 1. For processing the data the classifier of nonconformities for register was proposed.

\section{CLASSIFIER OF NONCONFORMITIES}

To classify the nonconformities the principle of three main fields recently most popular in certification of construction companies - quality, environment and work safety was chosen. These are the fields which are declared to be constantly bettering in many construction companies. Using the classifier the nonconformities are sorting by criteria reflecting the requirements to these three aspects. The analysis of defects and nonconformities let to identify the primary causes of defects and nonconformities. The determination of casual sequential links let to plan the correction actions and their direction more effectively (Figure 2).

According to proposed classifier the nonconformities are sorting by the following attributes: 1) nonconformity to quality requirements; 2) nonconformity to requirements of work safety; 3) nonconformity to requirements of environment safety. Each of these groups has the subgroups for classifying, which let to gain the more precise information about the nature of nonconformity (see figure 2). Information of register is regular, up to date and useful for different company activities involved in construction process. 


\begin{tabular}{|c|c|c|c|c|c|c|c|}
\hline $\begin{array}{l}\text { Responsible } \\
\text { for }\end{array}$ & \multicolumn{7}{|c|}{ Flow of actions } \\
\hline 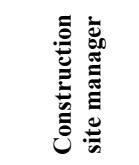 & \multirow{2}{*}{$\begin{array}{l}\text { Inspection } \\
\text { on } \\
\text { site }\end{array}$} & & $\begin{array}{l}\text { Control the } \\
\text { correction } \\
\text { actions } \\
\text { performed by } \\
\text { subcontractor }\end{array}$ & & & & \multirow{3}{*}{ 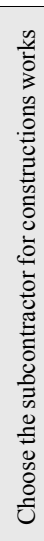 } \\
\hline 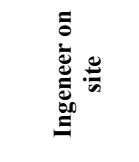 & & $\begin{array}{l}\text { Fill the } \\
\text { nonconformity } \\
\text { report. } \\
\text { Send it to } \\
\text { subcontractor }\end{array}$ & & $\begin{array}{l}\text { Put data to } \\
\text { register. } \\
\text { Analyse the } \\
\text { processed } \\
\text { results }\end{array}$ & $\begin{array}{l}\text { Send the } \\
\text { response to } \\
\text { procurement } \\
\text { manager }\end{array}$ & & \\
\hline 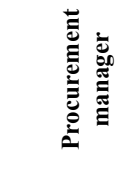 & & & & & & $\begin{array}{l}\text { Use the processed } \\
\text { data tables and } \\
\text { graphs for } \\
\text { subcontractor } \\
\text { precualification }\end{array}$ & \\
\hline
\end{tabular}

Figure 1. The procedure for recording and processing the nonconformities

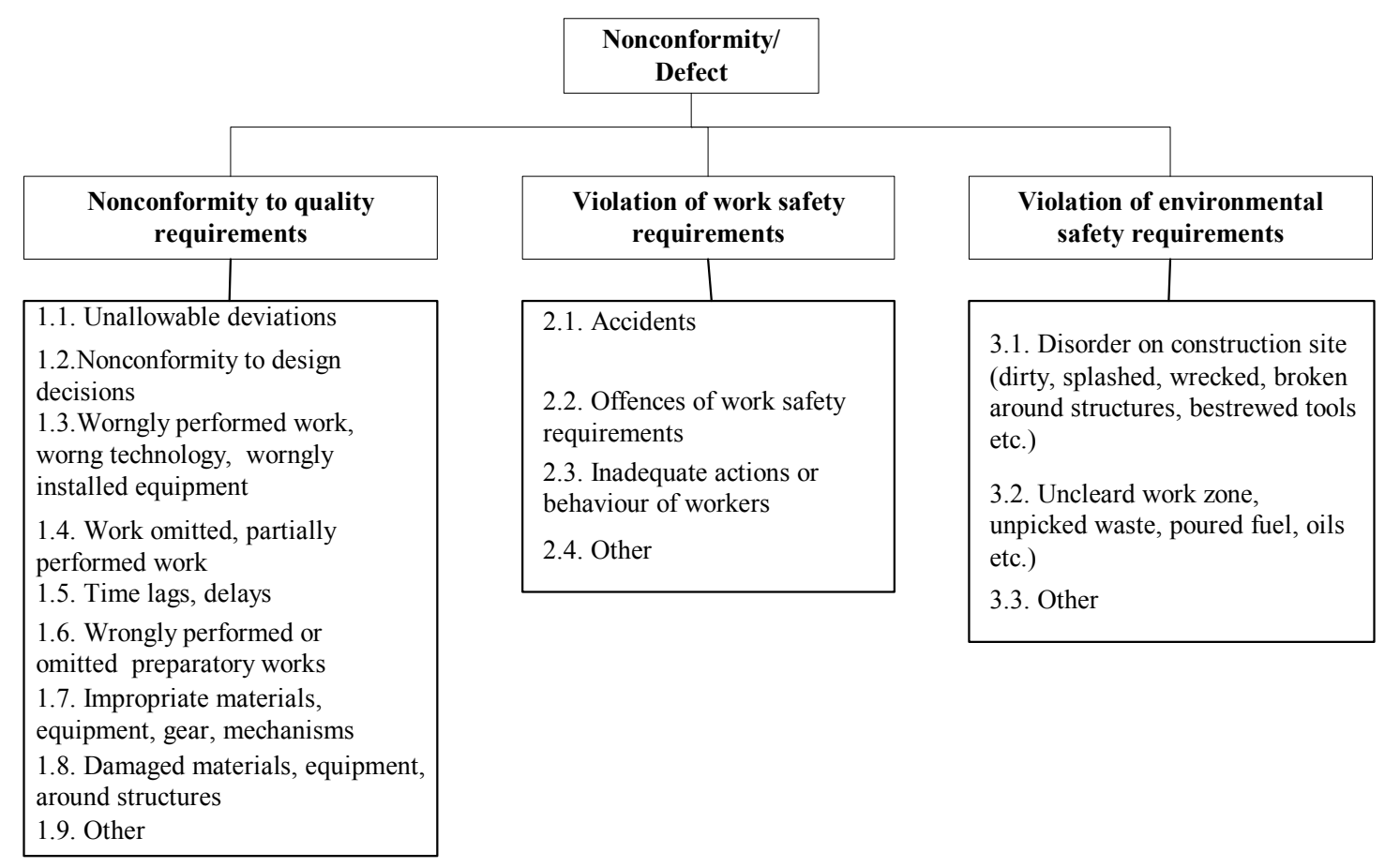

Figure 2. The grouping of nonconformities and defects in classifier 
For example, procurement department could use this information in subcontractor prequalification and selection process for further construction projects, construction managers could organize the monitoring of subcontractors works more effectively, for the information in register gives the awareness of how frequently and what kind of nonconformities are usually done by subcontractors.

To use the register practically the information from construction site should be gathered appropriately. The personnel of contractor usually fill the reports about the defects and nonconformities of subcon- tractors' work performance. This kind of report should consist of following information: the project number; the number of report; the date; the part of building were work was performed; the name of work performed; the short description of defect or nonconformity; the reference to drawings, specifications or other documentation containing the requirements; the description of corrective actions proposed by subcontractor; contractor confirmation for corrective actions. This report should be signed by responsible persons of both parties. The gathered data is processing in register of defects (Figure 3 ).

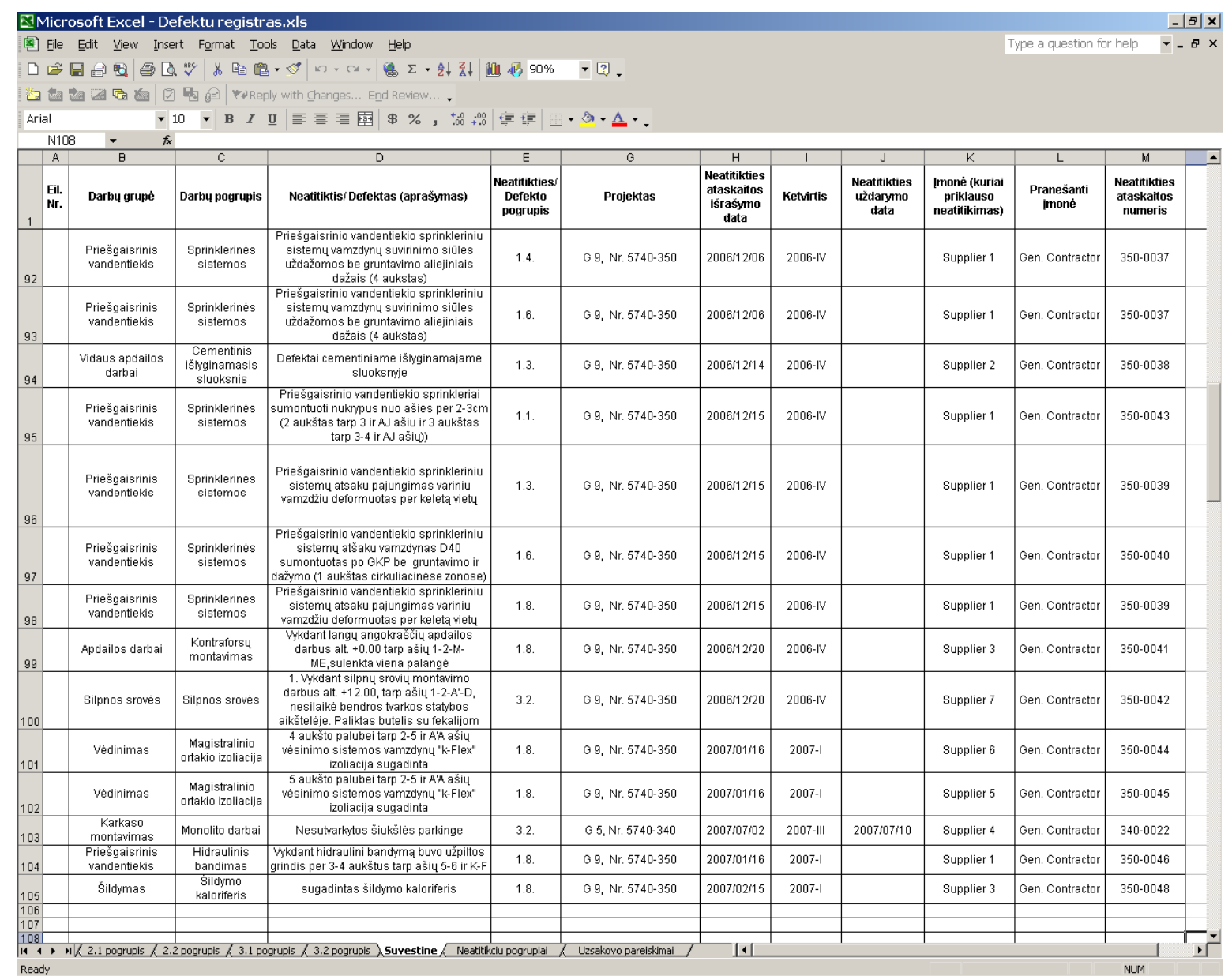

Figure 3. Data input window in register of defects 


\section{REGISTER OF DEFECTS}

To facilitate the analysis of defects and nonconformities, found and classified during the construction process, the register of defects was created. There the information from nonconformities reports filled on construction is incorporating. The report of nonconformities should be the real document available for all interested parties involved in project and saved at least till the end of warranty period.

In register data could be sorted by following attributes:

1. Group of work.

2. Subgroup of work.

3. Attributes of classifier.
4. The date of nonconformity corrective action/s and close off.

5. The project.

6. The date - year, quarter (time criterion).

7. Subcontractor company name (the one, which makes nonconformity).

The nonconformity/defect report number and the name of company which reports should be put in register.

The extract from the register of defects is shown in figure 3. processed data window in register of defects is presented in figure 4 .

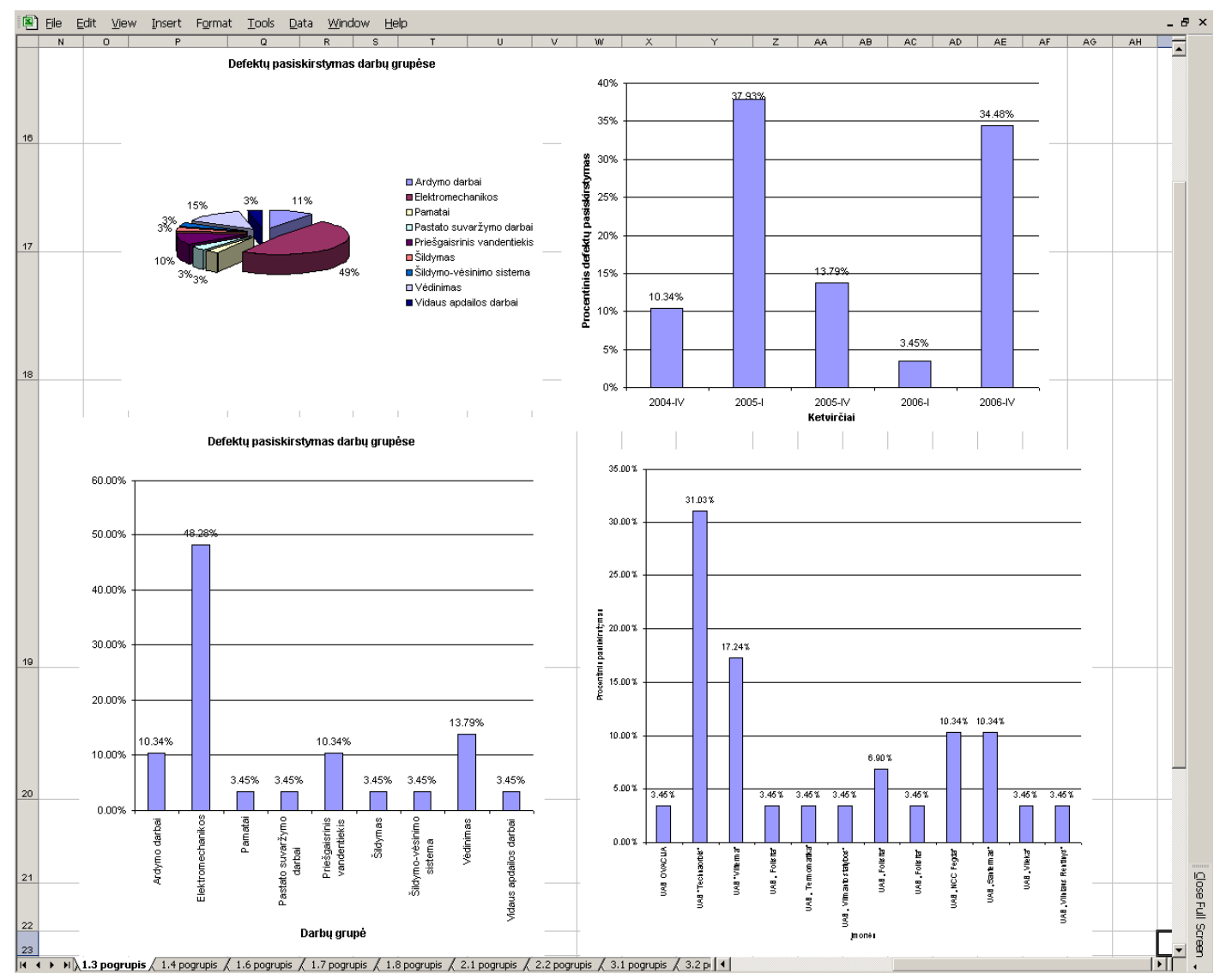

Figure 4. Processed data window in register of defects 


\section{CONCLUSIONS}

The practical usefulness of register of defects could be conveyed in following aspects:

1. The tool for quality inspections on construction site and constant improvement of processes. The register of defects is the tool for analysis, which let to determine the distribution of defects in different groups of work, in time and find the causes of defects. This information lets to determine the areas of special importance in each scope of work (were staff make errors more frequently) and facilitate the solution of problem find during the quality inspection.

2. The mean for project team to make decision. Responsible persons of project team (for example, the manager of construction works) could use the information in register as additional mean to determine the works were the high frequency of defects appearance was noticed and, therefore, need the particular attention.

3. The tool for training of new inexperienced staff. Construction site staff could determine the sources of potential threats and possible corrective actions more promptly.

4. The additional mean for prequalification procedure. Project team together with procurement department could use the information from register for prequalification process to evaluate the work quality (the earlier rate of defects and nonconformities in particular scope of work) of subcontractor.

\section{REFERENCES}

[1] Leung, S., Mak, S., Lee, B.L.P. (2008) Using a real-time integrated communication system to monitor the progress and quality of construction works, Automation in Construction, Vol. 17, p. 749-757.

[2] Josephson, P.E. and Hammarlund, Y. (1999) The causes and costs of defects in construction: a study of seven building projects. Automation in Construction, Vol. 8, Issue 6, p. 681-687.

[3] Hola B. (2007) General model of accident rate growth in the construction industry. Journal of Civil Engineering and Management, Vol XIII, Issue 4, p. 255-264.
[4] Hola., B. (2004) Analysis of accident situation in Polish construction industry in period preceding accession to the European Union. Journal of Civil Engineering and Management, Vol. 10 (Suppl 2), p. 107-113.

[5] Seeling, R. (2001) Possibilities of implementing the resolution No 92/57 ES of the Council of the EU ministries in Germany. Statyba (Civil Engineering), Vol. 7, Issue 4, p. 286-293.

[6] Sukys, R. (2004) Perspectives and problems of health and safety in construction. Journal of Civil Engineering and Management, Vol. 10 (Suppl 1), p. 51-55 (in Lithuanian).]

[7] Wang, L.-Ch. (2008) Enhancing construction quality inspection and management using RFID technology. Automation in Construction, Vol. 17, p. 467-479.

[8] Arslan, G., Kivrak, S., Birgonul, M.T., Dikmen, I. (2008) Improving sub-contractor selection process in construction projects: Web-based subcontractor evaluation system (WEBSES), Automation in Construction, Vol. 17, p. 480-488.

[9] Ng, S.Th. and Li, W. (2006) A parallel bargaining protocol for automated sourcing of construction suppliers, Automation in Construction Vol. 15, p. 365-373.

[10] Yang, J.-B., Wu, Ch.-T., Tsai, Ch.-H. (2007) Selection of an ERP system for a construction firm in Taiwan: A case study. Automation in Construction, Vol. 16, p. 787-796.

[11] Kadefors, A., Bjorlingson, E., Karlsson, A. (2007) Procuring service innovations: Contractor selection for partnering projects. International Journal of Project Management, Vol. 25, p. 375-385.

[12] Jang, W.-S. and Skibniewski, M.J. (2008) A wireless network system for automated tracking of construction materials on project sites. Journal of Civil Engineering and Management, Vol. 14, Issue 1, p. 11-19.

[13] Arslan, G., Tuncan, M., Birgonul, M.T., Dikmen, I. (2006) E-bidding proposal preparation system for construction projects. Building and Environment, Vol. 41, p. 1406-1413.

[14] Viteikienè, M. and Zavadskas, E.K. (2007) Evaluating the sustainability of vilnius city residential areas. Journal of Civil Engineering and Management, Vol. XIII, Issue 2, p. 149-155. 
[15] Palaneeswaran, E. and Kumaraswamy, M. (2001) Recent advances and proposed improvements in contractor prequalification methodologies. Building and Environment, Vol. 36, Issue 1, p. 73-87.

[16] Kaklauskas, A., Zavadskas, E.K., Banaitis, A. and Satkauskas, G. (2007) Defining the utility and market value of a real estate: a multiple criteria approach, $I n$ ternational Journal of Strategic Property Management, Vol. 11, Issue 2, p. 107-120.

[17] Topcu, Y.I. (2004) A decision model proposal for construction contractor selection in Turkey. Building and Environment, Vol. 39, p. 469-81.

[18] Russell, J. (1992) Decision models for analysis and evaluation of construction contractors. Construction Management and Economics, Vol. 10, Issue 3, p. 185-202.

[19] Mahdi, I.M., Riley, M.J., Fereig, S.M., Alex, A.P. (2002) A multi-criteria approach to contractor selection. Engineering, Construction and Architectural Management, Vol. 9, Issue 1, p. 29-37.

[20] Zavadskas, E.K. and Vilutiene, T. (2006) A multiple criteria evaluation of multi-family apartment block's maintenance contractors: I-Model for maintenance contractor evaluation and the determination of its selection criteria. Building and Environment, Vol 41, Issue 5, p. 621-632.

[21] Ng, S.T. and Skitmore, R.M. (1999). Client and consultant perspectives of prequalification criteria. Building and Environment, Vol. 34, Issue 5, p. 607-21.

[22] Russell, J., Hancher, D, Skibniewski, M. (1992) Contractor prequalification data for construction owners. Construction Management and Economics, Vol. 10, Issue 2, p. 117-35.

[23] Hatush, Z and Skitmore, M. (1998) Contractor selection using multi-criteria utility theory: an additive model. Building and Environment, Vol. 33, Issue 2-3, p. 105-15.

[24] Watt, D.J., Kayis, B., Willey, K. (2008) Identifying key factors in the evaluation of tenders for projects and services, International Journal of Project Management, Article in press.

[25] Lambropoulos, S. (2007) The use of time and cost utility for construction contract award under European Union Legislation, Building and Environment, Vol. 42, p. 452-463.

[26] Ling, F.Y.Y. (2004) How project managers can better control the performance of design-build projects, International Journal of Project Management, Vol. 22, p. 477-488. 